\section{Mechanisms in minds}

Current Biochemical Approaches to Learning and Memory. Edited by Walter B. Essman and Shinshu Nakajima. Pp. ix +205 . (Monographs in Modern Neurobiology.) (Spectrum: Flushing, New York; distributed by Halsted (Wiley), March 1974.) $£ 8.40$.

ThIS book consists of an introductory chapter by the two editors, and eight chapters devoted to current research in the area of biochemistry and learning. The first chapter is a short, readable and sensible historical review, and the only chapter for which there would seem to be any excuse for publication. The remaining chapters are brief, superficial, badly written, and poorly edited; mistakes in spelling and punctuation, and peculiarities of grammar are common throughout, particularly in those chapters by authors whose first language is, as is all too evident, not English. There is not even any consistency in the way in which references are set out, some authors giving titles of papers, and others, page numbers only.

The brevity of the chapters has two unfortunate effects; first, no attempt is made to place the research described in a wider setting, by showing its relationship to the often very large body of relevant material from other laboratories. Bogoch, for example has a reference list of 29 entries, 28 of which are to his own work; Tsukada has one reference (to Tsukada). In some cases, there is a distinct impression that the authors are simply unaware of the research carried out in other laboratories - the chapter by Ilyutchenok and his colleagues on cholinergic mechanisms does not refer at all to Carlton, and only in passing to Deutsch.

The other consequence of brevity is that the evidence in support of authors' claims is very rarely presented in sufficient detail to allow its evaluation, and frequently no very clear idea emerges of exactly what procedures were used. What little hard evidence is provided is distinctly discouraging, displaying as it does, in almost every chapter, a cavalier attitude to statistics. For example, Fjerdingstad, in the only chapter on transfer of learning, applies one-tailed $U$ tests to each of several test sessions on the same animals, without any regard to the fact that acceptable significance levels change drastically with such a technique. Whether such considerations would influence the editors is open to doubt. Nakajima in his chapter reports an experiment, with six groups of eight animals each; although he first states that the number of animals is insufficient for statistical analysis, he nevertheless goes on to tell us that the results "suggest" one conclusion and "also indicate" another.
In short, this is a book that should never have been published. It is extremely expensive, and one can only hope that few institutions, and fewer individuals, will feel obliged to purchase it.

Euan M. Macphail

\section{Plants in action}

Dynamic Aspects of Plant Ultrastructure. Edited by A. W. Robards. Pp. xii+546. (European Plant Biology Series.) (McGraw-Hill: London and New York, June 1974.) £8.95.

DR RoBards has brought together seventeen distinguished workers to write fifteen chapters in his symposium. It is difficult to fault either the credentials or the international flavour of the chosen authors. The advantage of the symposial approach is that each section can be written at the front of knowledge of that topic and, given a firm editor which has here been achieved, a relative evenness of treatment is possible. My quarrels with statements made by individual authors are of the level to be settled at small conferences and not of major substance. The disadvantage of the symposial approach is that each author is constrained to write within a precise framework and this inhibits cross correlations or interpretative sections on, for example, overall control mechanisms or communication between cells. A book of this type, excellent

\section{Erotic tree}

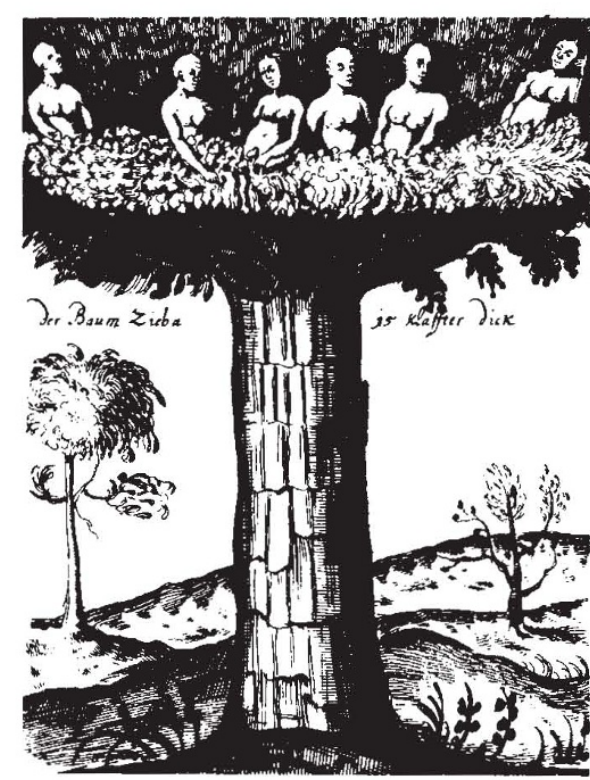

The Zieba tree, described in 1676 by Christopher Vielheuern. From Bizarre Plants: Magical, Monstrous, Mythical by William A. Emboden. Pp. ix +214 . (Studio Vista, London, 1974.) £2.95. as it is, must therefore be read in conjunction with single-author works at the same level.

Errors are few and good references numerous. Economies such as the lack of line 'justification' are justified and bother me not at all. But was it worth putting in some, only just relevant, expensive colour plates and printing all the rest of the plates on muddy matt paper even muddier than Dr Robards's previous text in this series? It does hold the price down to a reasonable level, but it must have enraged the authors of some of the beautiful micrographs included.

B. E. JUNIPER

\section{Techniques for analysis}

Analytical Chemistry: An Introduction. By Donald J. Pietrzyk and Clyde W. Frank. Pp. $x x+667$. (Academic: New York and London, April 1974.) \$13.95; £6.70.

THE course described in this book was originally designed as a one-semester introductory course in analytical chemistry for subsidiary students, but it is now intended for students taking chemistry as their major subject. There are four main areas: spectroscopy, acid-base methods, potentiometry with special reference to ion selective electrodes and chromatography. These topics are subdivided into further parts.

Analytical chemistry now covers such a broad area that only in specialised courses can it be treated in depth. An introductory course should set out to show what techniques are available and provide some guidance as to which are suitable for a particular purpose. Generally, in an introductory course the main limitation is time and therefore a very careful selection has to be made.

The authors of this book have obviously given a great deal of thought to the problem, for this is a well balanced course presenting information on all the basic methods and techniques of analytical chemistry. A balanced picture of the respective parts played by instrumental and classical analysis is also provided.

Some excellent exercises are described and possibly the only criticism to be made here is the omission of one on solvent extraction; it is a curious fact that most teaching texts on analytical chemistry avoid this exercise, despite the importance of the subject. Another criticism is that a better selection of redox indicators might have been provided; the quoted potentials of some are incorrect.

These are very minor shortcomings and in general this is an admirable and well thought out text which all teachers of analytical chemistry should find of great value.

R. BELCHER 